\title{
Trade, Infrastructure and Transaction Costs: The Imperatives for Asian Economic Cooperation
}

\author{
Prabir De \\ Research and Information System for Developing Countries (RIS)
}

\begin{abstract}
Recent literature has emphasized the importance of transaction costs and infrastructure in explaining trade, access to markets, and regional cooperation under globalization. For most Asian countries, transaction costs are a greater barrier to trade integration than import tariffs. By estimating a structural model of economic geography using cross-country data on income, infrastructure, transaction costs and trade of selected Asian economies, this paper shows that the transaction costs is statistically significant and important determinant in explaining variation in trade in Asia.
\end{abstract}

- JEL classification: F02, F10, F15

- Keywords: Asia, Gravity Model, Infrastructure, Transaction Costs, Trade

\section{Introduction}

In traditional trade theory it is customarily assumed that trade takes place between countries which have no spatial dimensions. Correspondingly, locational problems have also been neglected in the theory of customs unions. In 1961, Bella Balassa, the then associate professor at the Yale University, published a book entitled The Theory of Economic Integration. ${ }^{1}$ Even though very few are aware of it, this book propounded the view that success of global trade is characterized by 'economic distances' among the trading pairs. This led to generate a new chapter in international trade, in which the success of trade liberalization depends very much

\footnotetext{
*Corresponding address: Prabir De, Research and Information System for Developing Countries (RIS), India Habitat Centre, Zone 4-B, Lodi Road, New Delhi 110 003, India, Phone: (+91-11) 2468 2177-80, Fax: (+91-11) 2468 2173-74, E-mail: prabirde@hotmail.com; prabirde@ris.org.in (C2006-Center for International Economics, Sejong Institution, All Rights Reserved.
} 
on countries ability to control 'non-price factors' of trade.

But while the rhetoric of trade costs has proved very appealing to common people, the analytical basis for the concept is somewhat unclear. If trade between two countries (or among a group of countries) normally raises real income in both; does it mean anything to say that countries may not have to deal with trade costs separately as if these are by default taken care by production costs? Several studies, mostly in context of EU and WTO, show that it is possible that a trading economy(s) may hurt if trade costs are not dealt separately, particularly when there exists structural (artificial or natural or both) asymmetries within or between the trading pairs. ${ }^{2}$ Therefore, one of the supposed objectives of trade liberalization is, thus, been to reduce trade barriers - quantitative and qualitative.

While the world has witnessed drastic fall in tariffs over the last two decades, a whole lot of barriers remain and do penalizing trade, among which some are seen as 'soft' barriers and others as 'hard' barriers. One set of such 'soft' barriers are dealt through measures in trade and business facilitation. The 'hard' set of barriers, which are often cited as physical or infrastructure barriers, are dealt through transport facilitation measures. In a different vein, the costs appearing from these barriers can be clubbed together, and, for the sake of understanding, is termed as 'trade costs', which is measured as a mark-up between export and import prices. This mark-up roughly indicates the relative costs of transfer of goods from one country to another country thereby can be commented as an approximation to capture the Balassa's 'economic distance'.

Quite naturally, economic integration is the resultant of reduced costs of transportation in particular and other infrastructure services in general. This is particularly applicable to the case of trading for the vast mass of developing countries. It is directly beneficial to those industries which are efficient; indirectly, it also creates a positive growth chain through higher productivity thereby generating many new economic activities in the domestic economy. In an economy-wide sense, it may work as a poverty removal process too. But in order to reap the benefits of globalization in the present "borderless" world, no country can afford to relax on the overhead development of the chain of necessary infrastructure facilities starting from the production point leading to the shipment point.

\footnotetext{
${ }^{1}$ Refer, Balasaa (1961)

${ }^{2}$ Refer, Refer De $(2004,2005,2006)$ for the list of studies which have dealt so far the theoretical and empirical causal relationship between trade flow and trade costs.
} 
Asia being an emerging economic bloc has seen a spread of regional integration and cooperation initiatives in recent past. In one hand, trade volume in Asia has been rising at a rapid speed, and on the other, the pattern and characteristics of trade have been changing very fast. Countries in Asia are gradually specializing in trade in intermediate goods where cost of trade is also high subject to variability of barriers. How are the Asian countries doing in managing those barriers? Is there any comprehensive attempt to measure such barriers at a full length? When there is spurt of growing regionalism in Asia (for example, East Asia Summit of 2005), there is an urgent need to understand the relationship between trade flow and barriers to trade. which is required for long term development. Moreover, there is dearth of studies to establish an appropriate causality of factors required for policy framework. The question then arises: how do the non-price determinants of international trade such as infrastructure and transaction costs affect integration of Asia? This study is aimed to deal this objective in context of selected Asian countries.

To find out the answer to above question, we use a Gravity model of trade, controlling for geographic, economic, political factors, transaction costs, and free trade regime coordination. The paper is organized as follows. Section 2 deals with data and methodology. In Section 3, we present income, infrastructure and trade profiles of selected Asian economies. Section 4 presents with the Gravity results. Section 5 concludes and summarizes our main findings.

\section{Data and Methodology}

In order to explore the impact of transaction costs on trade flows, our empirical analysis has considered an augmented Gravity model since it is the most robust partial equilibrium model known in explaining the variation of trade flows. The Gravity model provides the main link between trade barriers and trade flows. ${ }^{3} \mathrm{We}$ look at the trade flows by estimating a Gravity model including income, infrastructure and host of institutional and economic variables. There are two important reasons for doing this. First, the variables are identified keeping in mind their importance in influencing bilateral trade. Second, we can estimate elasticity of trade flows with respect to exogenous variables.

$$
T_{i j}=C Y_{i}^{\theta 1} Y_{j}^{\theta 2} D_{i j}^{\theta 3} e_{i j}
$$


where $\mathrm{T}_{i j}$ is the international trade flow from country $i$ to country $j, \mathrm{C}$ is the constant term, $\mathrm{Y}_{i}$ is the income level of the origin country, $\mathrm{Y}_{j}$ is the income level of the destination country, $\mathrm{D}_{i j}$ is the distance between the two countries, $\mathrm{e}_{i j}$ is an error term.

We analyze the aforesaid Gravity model extended to use data on trade, distances, gross domestic product (GDP), per capita GDP, infrastructure, openness, export and import duties, and exchange rate for 15 Asian economies, namely, Brunei, Cambodia, China, Hong Kong, India, Indonesia, Japan, Lao PDR, Malaysia, Myanmar, Philippines, Singapore, South Korea, Thailand, and Vietnam, which we term here as Asia. ${ }^{5}$

Bilateral trade data are collected from various issues of Direction of Trade Statistics Yearbook (DOTS) of International Monetary Fund (IMF). This dataset is supple-mented, as and when required, by ASEAN trade data. ${ }^{6}$ Data on GDP, population, and infrastructure are collected from World Development Indicators (WDI) CD ROM 2006 of World Bank. ${ }^{7}$ Asian Development Bank's ADB Key Indicators 2005 was also used as and when felt necessary. ${ }^{8}$ In case of calculation of distance between countries, we have used two methods - (a) 'capital to capital' distance

\footnotetext{
${ }^{3}$ The Gravity model has been used extensively in social and behavioral sciences. In analogy to the Newtonian Gravity model, James Q. Stewart $(1947,1948)$ found strong correlations for traffic, migration, and communication between two places, based on the product of the population size and inversely related to their distance squared. This model became popular in the hand of Jan Tinbergen (1962) when it was applied to international trade. Since then the Gravity equation has become a standard analytical tool for prediction of bilateral trade flows with simultaneous development of its theoretical discourse. Although there is debate about its theoretical support, the Gravity equation is one of the most empirically successful in economics. It relates bilateral trade flows to GDP, distance, and other factors that affect trade barriers. It has been widely used to infer trade flow effects of institutions such as customs unions, exchange-rate mechanisms, ethnic ties, linguistic identity, international borders, and so on and so forth. See, for example, Anderson (1979), Deardoff (1998), Hummels (1999), Baier and Bergstrand (2001), Limao and Venables (2001), Glick and Rose (2002), Fink et al (2002, 2005), Wilson et al (2003), etc.

${ }^{5}$ This is not to contradict with views of any inter-Governmental body or United Nations about the definition of Asia. Here terming selected 15 Asian economies, which together represent ASEAN+4 countries, is purely academic in nature. ASEAN includes Brunei, Cambodia, Indonesia, Lao PDR, Malaysia, Myanmar, Philippines, Singapore, Thailand, and Vietnam. For the sake of analysis, Hong Kong (china) is treated as separate economy in this paper.

${ }^{6}$ Available on-line at http://www.aseansec.org/home.htm
${ }^{7}$ Although most of the data series was collected from WDI CD-ROM 2006, some part of the data series relating to port and shipping was collected by the authors from port-related sources such as Containerisation International Year Book.

${ }^{8}$ Available at http://www.adb.org/Documents/Books/Key_Indicators/2005/default.asp 
using the longitude and latitude when countries share common land border such as Cambodia and Lao PDR, ${ }^{9}$ and (b) 'port to port' distance for the rest. ${ }^{10}$

\section{Estimating Transaction Costs}

Transaction costs are often cited as an important determinant of the volume of trade. ${ }^{11}$ Despite a wide range of theoretical derivations of the Gravity equation, the majority of the authors do not model transaction costs explicitly, exceptions being Bergstrand (1985, 1989), David (1998), Deardorff (1998), Limao and Venables (2001), Fink et al., (2002), Clark, Dollar and Miucco (2004), Redding and Venables (2004), Hummels (2001a, 2001b), Wilson et al, (2003). However, except Limao and Venables (2001) and De $(2005,2006)$, none has incorporated both infrastructure and trade costs in the model.

To estimate bilateral transaction cost in this study, we have followed the method introduced by Limao and Venables (2001), following the difference of cif (cost, insurance and freight) and $f o b$ (free on board) values. ${ }^{12}$ Importing countries report the value of imports from partner countries inclusive of cif, and exporting countries report their value on $f o b$, which measures the cost of the imports and all charges incurred in placing the merchandise aboard a carrier in the exporting port. Let Tij denotes the unit cost of shipping a particular good from country $j$ to country $i$. We suppose that it is determined by:

\footnotetext{
${ }^{9}$ Obtained from http://www.indo.com/distance

${ }^{10}$ Calculated using SUDist Version 1.0, available at http://www.shipanalysis.com

${ }^{11} \operatorname{Refer}$ De $(2004,2005,2006)$ for the list of studies which dealt so far the theoretical and empirical causal relationship between trade flow and trade costs.

${ }^{12}$ Many techniques have been constructed to measure transaction costs. The most straightforward measure in international trade is the difference between the cif and fob quotations of trade. The difference between these two values is a measure of the cost of getting an item from the exporting country to the importing country. See, Brakman, Garretsen and Marrewijk (2001) for further details. There is another source to obtain data for transport costs from industry or shipping firms. Limao and Venables (2001) obtained quotes from shipping firms for a standard container shipped from Baltimore to various destinations. Hummels (2001a) obtained indices of ocean shipping and air freight rates from trade journals which presumably are averages of such quotes. Due to data limitations and the very large size of the resulting datasets, direct methods are best but not always feasible here. The most widely available (many countries and years are covered) is average ad-valorem transport costs are the aggregate bilateral cifffob ratios from UN's COMTRADE database, supplemented in some cases with national data sources. Nevertheless, because of their availability and the difficulty of obtaining better estimates for a wide range of countries and years, apparently careful work such as Harrigan (1993) and Baier and Bergstrand (2001) used the IMF (COMTRADE) database.
} 


$$
T_{i j}=f\left(x_{i j}, X_{i}, X_{j}, m_{i j}\right)
$$

where $x_{i j}$ is a vector of characteristics relating to the journey between $i$ and $j, X_{i}$ is a vector of characteristics of country $i, X_{j}$ is a vector of characteristics of country $j$, and $\mu_{i j}$ represents all unobservable variables.

Denoting the fob price shipped from $j$ to $i$ by $p_{i j}$, we define $t_{i j}$, the ad-valorem transaction cost factor, as

$$
t_{i j}=c i f_{i j} / f o b_{i j}=\left(p_{i j}+T_{i j}\right) / p_{i j}=t\left(x_{i j}, X_{i}, X_{j}, \mu_{i j}\right)
$$

where the determinants of $T_{i j}$ are given in equation (2). The ratio of ( $c i f / f o b$ ) provides the measure of transaction costs on trade between each pair of countries. Assuming that $t_{i j}$ can be approximated by a log linear function up to some measurement error, the average observed transaction cost rates $t_{i j}$ appears as follows.

$$
\ln t_{i j}=\alpha+\ln \beta x_{i j}+\gamma \ln X_{i}+\delta \ln X_{j}+\omega_{j}
$$

Following Limao and Venables (2001), in terms of the data, $t_{i j}$ corresponds to the ratio $\left[(c i f / f o b)-1=\left(I M_{i j}^{t} / E X_{j i}^{t}\right)-1\right]$ for importing country $i$. The ratio (ciflfob1) represents the ratio of unit transaction costs to the $f o b$ price and thus provides a simple summary statistic of the transaction cost on imports. As pointed out by Limao and Venables (2001), ciflfob data does contain information about the cross sectional variation in transport costs, and that results from using this data are quite consistent with those obtained from the shipping cost data. ${ }^{13}$

Here, the transaction costs, $T C_{i j}\left(=t_{i j}\right)$ represents costs of transaction between country $i$ and $j$ for the period $t, I M_{i j}$ stands for import (cif) of country $i$ from country $j$ for the period $t$, and $E X_{j i}^{t}$ denotes export $(f o b)$ of country $j$ to country $i$ for the period $t$. This means that the same items from reverse directions are considered

\footnotetext{
${ }^{13}$ However, cif / fob ratio has some drawbacks. The first is measurement error; the cif / fob factor is calculated for those countries that report the total value of imports at cif and fob values, both of which involve some measurement error. The second concern is that the measure aggregates over all commodities imported, so it is biased if high transport cost countries systematically import lower transport cost goods. This would be particularly important if we were using exports, which tend to be concentrated in a few specific goods. It is less so for imports which are generally more diversified and vary less in composition across countries (Limao and Venables, 2001).
} 
for accounting purpose.

\section{Estimating Transport Infrastructure}

Country's infrastructure plays vital role in carrying trade, which has been widely dealt in several studies. For example, by incorporating transport infrastructure in a two-country Ricardian framework, Bougheas et al. (1999) have shown the circumstances under which it affects trade volumes. ${ }^{14}$ According to Francois and Manchin (2006), transport and communication infrastructure and institutional quality are significant determinant not only for country's export levels but also for the likelihood exports. Nordås and Piermartini (2004) shown that quality of infrastructure is an important determinant of trade performance wherein port efficiency alone has the largest impact on trade among all indicators of infrastructure.

The infrastructure variables have explanatory power in predicting trade volume. Limao and Venables (2001) emphasized the dependence of trade costs on infrastructure, where infrastructure is measured as an average of the density of the road network, the paved road network, the rail network and the number of telephone main lines per person. A deterioration of infrastructure from the median to the 75th percentile of destinations raises transport costs by 12 percent. The median landlocked country has transport costs which are 55 percent higher than the median coastal economy. ${ }^{15}$ Inescapably, understanding trade costs and their role in determining international trade volumes must incorporate the internal geography of countries and the associated interior trade costs.

In this study, for country characteristics, we have focused on infrastructure measures - the country's ability to enhance the movement of merchandise. To assess impact of transport infrastructure facilities on bilateral trade, we have constructed transport infrastructure index (TII), comprising rail, road, air and port facilities for each individual country using principal component analysis. ${ }^{16}$ Briefly, the TII is a linear combination of the unit free values of the individual facilities such that

\footnotetext{
${ }^{14}$ Bougheas et al. (1999) estimated augmented Gravity equations for a sample limited to nine European countries. They included the product of partner's kilometers of motorway in one specification and that of public capital stock in another and found that these have a positive particle correlation with bilateral exports.

${ }^{15}$ Limao and Venables (2001) also reported similar results using the cifffob ratios of the IMF.

${ }^{16} \mathrm{~A}$ basic limitation of the conventional method of indexation is that while combining the actual facilities it gives ad hoc and fixed weights to different facilities that may actually vary over time and space depending on their significance. To overcome this limitation we have employed here the well-known multivariate technique of factor analysis or principal component analysis, PCA (Fruchter, 1967).
} 


$$
T I I_{i j}=\sum W_{k j} X_{k i j}
$$

where $\mathrm{TII}_{i j}=$ transport infrastructure development index of the i-th country in jth time, $\mathrm{W}_{k j}=$ weight of the $\mathrm{k}$-th facility in $\mathrm{j}$-th time, and $\mathrm{X}_{k i j}=$ unit free value of the k-th facility for the $\mathrm{i}$-th country in $\mathrm{j}$-th time point. In subsequent regressions, we prefer to take an inverse measure of TII so that an increase in TII is expected to be associated with an increase in the TC, and vice versa. ${ }^{17}$ The TII is designed to measure the costs of travel in and through a country. In theory the fob and cif prices are border prices and thus it would seem that own and trading partner infrastructures as defined here should not affect these rates. It is possible that there are interactions between the cost variables, which would make a nonlinear form more suitable. The simplest example is that an increase in land distance should increase the cost of going through a given infrastructure.

To assess impact of exchange rate on trade, we have considered the standard deviation of the bilateral annual official exchange rates for the previous three years as the measure of exchange rate volatility. Besides, openness (as the ratio of trade and GDP) and export and import duties on traded goods were also incorporated into the analysis.

The dataset includes bilateral trade between 15 Asian economies for the years 2000 to 2004. There are 17 variables (excluding two dummies) which make the dataset as 7140 pooled observations. In order to understand the effects of common border (land) and regional and/or bilateral preferential and/or free trade agreements, we have included two dummies, namely, common border dummy and free trade dummy.

\section{The Model}

Instead of looking directly at trade costs, we look at the trade flows between countries by estimating a Gravity model including income, infrastructure and host of institutional and economic variables as reported above. There are two important reasons for doing this. First, the variables are identified keeping in mind their importance in influencing bilateral trade. Second, we can estimate elasticity of trade flows with respect to all exogenous variables. Although the Gravity equation is the standard analytical framework for the prediction of bilateral trade flows, we

\footnotetext{
${ }^{17}$ Due to limitation of space, we are avoiding placing details on the construction of the infrastructure indexes along with respective weights derived from principal component analysis, which will be available on request from the author.
} 
restrict ourselves only into comparative static policy simulation rather than extending it for forecasting purposes. The Gravity equation which we have estimated in log-linear form is as follows.

$$
\begin{gathered}
\ln I M_{i j}=\alpha_{0}+\alpha_{1} \ln G D P_{i}+\alpha_{2} \ln G D P_{j}+\alpha_{3} \ln G D P P C_{i}+\alpha_{4} \ln G D P P C_{j}+\alpha_{5} \\
\ln T I I_{i}+\alpha_{6} \ln T I I_{j}+\alpha_{7} \ln O N S_{i}+\alpha_{8} \ln O N S_{j}+\alpha_{9} \ln T C_{i j}+\alpha_{10} \ln I M D_{i}+\alpha_{11} \ln \\
E X D_{j}+\alpha_{12} \ln E R V_{i}+\alpha_{13} \ln E R V_{j}+\alpha_{14} \ln D_{i j}+\alpha_{15} C B_{i j}+\alpha_{16} F T A_{i j}+\varepsilon_{i j}
\end{gathered}
$$

where $i$ and $j$ are importing and exporting countries respectively, $\mathrm{IM}_{i j}$ represents import of country $i$ from country $j$, GDP is country's gross domestic products, taken at current US \$, GDPPC stands for country's per capita gross domestic products, considered in current US \$, TII represents country's transport infrastructure index, ONS is country's openness, measured in terms of trade as percentage of country's GDP, TC stands for transaction costs for bilateral trade between countries $i$ and $j$, IMD and EXD stand for country's import and export duties respectively, calculated separately as percentage of country's total tax revenue, ERV is exchange rate volatility, $\mathrm{D}_{i j}$ is the distance between countries $i$ and $j$, and $\varepsilon_{i j}$ is error terms. $\mathrm{CB}_{i j}$ stands for common border dummy for bilateral trading between countries $i$ and $j$ ( $=1$ for having land border, 0 otherwise) whereas $\mathrm{FTA}_{i j}$ represents Free (preferential) Trade Agreement dummy between countries $i$ and $j$ ( $=1$ for having free or preferential trade agreement, 0 otherwise).$^{18}$

\section{Income, Infrastructure and Trade in Asia}

\section{A. Inequality in Income}

There is a consensus among the proponents of free trade that in the absence of economic integration, the paradigm of globalization is likely to be operationally dysfunctional; a small subset of economies commands much larger shares of world output and trade while a large number of economies have rather marginal shares in world output and trade. So, disparity prevails in economy, society and life. This is not desirable from either point of view. An integration process among different economies must reduce disparity among its members over time (Georgakopoulos

\footnotetext{
${ }^{18}$ Note that since a few observations are with zero trade, the dependent variable is the log of 1 plus imports. Having censored data normally requires Tobit estimation, but for Gravity models this has typically made little difference (Eichengreen and Irwin, 1998).
} 
et. al, 1994). Before we comment anything on welfare distribution effects of Asian integration process, it would be worthwhile to look into the present economic structure of the selected Asian economies. Let us turn to Table 1.

The population dynamics has very nice properties for these economies as can partly be seen from Table 1. Both rising population with resource (man made) limitations and decreasing/static population with abundant resources have been termed as 'threat' towards growth of an economy. The same is reflected here. Interestingly, countries which have registered de-growth in population have been faced with low growth of their economies and thereby income over time. While this may not be unquestionably true across board for most of the countries in Asia, interestingly, this is highly acceptable for the developed economies such as Japan and South Korea. In general, Asia has registered lower growth of population rate during the decade from 1991 to 2001 compared to the previous decade; overall population growth rate has come down from 1.86 percent to 1.41 percent. Except Singapore, rest 14 members of Asia have registered lower population growth rate

Table 1. Population and Income

\begin{tabular}{lccccc}
\hline \multirow{2}{*}{ Countries } & $\begin{array}{c}\text { Population } \\
\text { Density }\end{array}$ & \multicolumn{2}{c}{$\begin{array}{c}\text { Population } \\
\text { Growth Rate* }\end{array}$} & \multicolumn{2}{c}{$\begin{array}{c}\text { GDP Per Capita } \\
\text { Growth Rate** }\end{array}$} \\
\cline { 2 - 6 } & Pop./Sq. Km & \multicolumn{2}{c}{$\%$} & \multicolumn{2}{c}{$\%$} \\
\cline { 2 - 6 } Brunei & 2001 & $1981-1991$ & $1991-2001$ & $1981-1991$ & $1991-2001$ \\
Cambodia & 60 & 3.29 & 2.99 & dna & 0.58 \\
China & 68 & 3.54 & 3.00 & dna & 2.69 \\
Hong Kong & 133 & 1.58 & 1.05 & 11.79 & 13.28 \\
India & 6238 & 1.24 & 1.69 & 6.12 & 2.51 \\
Indonesia & 314 & 2.33 & 1.91 & 3.51 & 4.89 \\
Japan & 110 & 1.98 & 1.53 & 5.60 & 2.44 \\
Lao PDR & 336 & 0.53 & 0.25 & 4.22 & 0.82 \\
Malaysia & 23 & 2.99 & 2.75 & dna & 4.65 \\
Myanmar & 72 & 3.23 & 2.76 & 3.84 & 4.19 \\
Philippines & 71 & 1.98 & 1.72 & dna & dna \\
Singapore & 261 & 2.69 & 2.54 & -1.04 & 0.99 \\
South Korea & 6663 & 2.38 & 3.17 & 5.95 & 4.79 \\
Thailand & 477 & 1.17 & 0.94 & 11.04 & 5.66 \\
Vietnam & 119 & 1.84 & 0.84 & 8.44 & 3.36 \\
Average AEC & 240 & 2.35 & 1.76 & 1.02 & 7.79 \\
\hline Notes: Average & 169 & 1.86 & 1.41 & 5.25 & 4.19 \\
\hline
\end{tabular}

Notes: *Average annual. **GDP Per Capita taken at constant 1995 US \$**dna means data not available Source: World Development Indicators 2006 CD ROM, World Bank. 
in 1990s, whereas, at the same decade, average per capita income of Asia was grown by lower rate (4.19 percent) than that of 1980s (5.25 percent). Except China, India, Malaysia and Vietnam, per capita income of rest of the Asian members has registered lower growth rate during this period. Thus, those countries which are placed above the fitted line in Figure 1 appear to have been the newly rising nations in Asia.

Figure 1 also brings enough justification for opening a regionalization process for the entire Asia. In last two decades, only four countries, namely, China, India, Malaysia and Vietnam, have done well in raising their per capita incomes. Interestingly, these are the nations (except Malaysia) along with Cambodia, Lao PDR and Myanmar who happen to be relatively poor compared to the rest. Hence the emerging tendency coming out of Figure 1 is a bit encouraging for Asia's economic future.

In Figures 2(a, b), we present evidence on the lack of cross-country convergence in these economies. From the first diagram it appears to be quite obvious that the relative positions of these countries have not changed at all over last three decades. In terms of cross- country growth experiences as discoursed by Barro and Sala-iMartin (1995), this phenomenon has tremendous economic implications for Asian economic cooperation. For the simplest test of such phenomenon let us turn to

Figure 1. Decadal Growth Rates of GDP Per Capita of Asian Countries

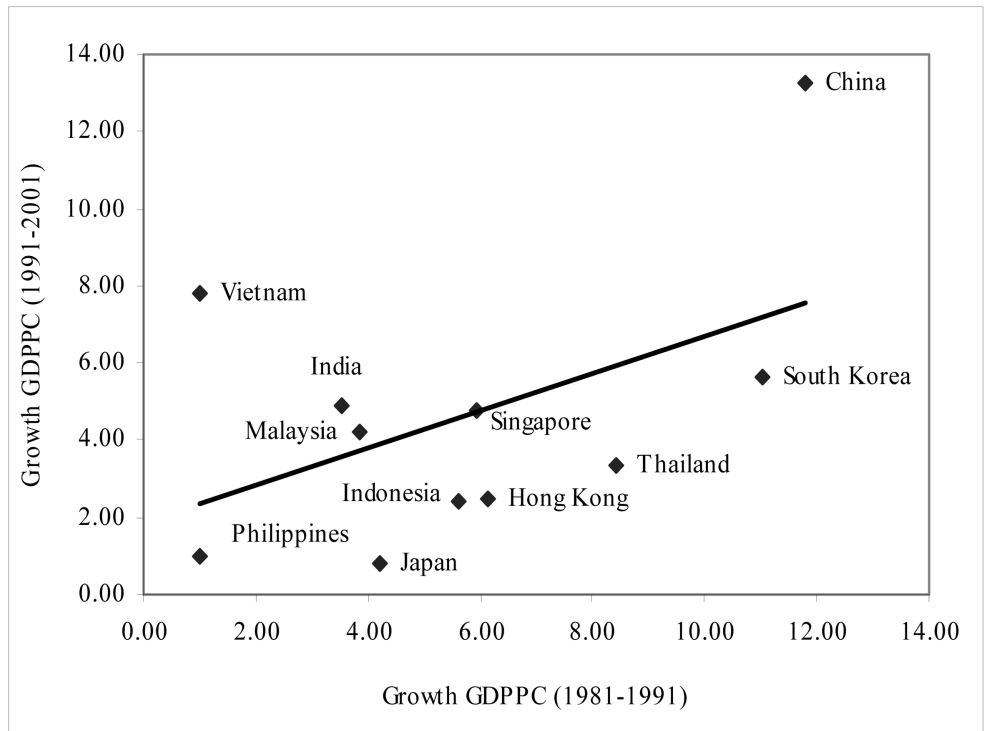

Note: *GDP Per Capita taken at constant 2000 US \$. 
Figure 2 (b) which presents base period GDP per Capita Income (GDPPCI) and long period growth rates of GDPPCI. As obvious from this figure, divergence is not the general outcome for the economies under discussion with Japan and China taking the two clear extremes in a very understandable way like a European cluster. Moreover, Korea, Singapore and Hong Kong take the three intermediate positions in a predictable fashion. Hence, there appears to be a desirable tendency towards convergence in this part of Asia as the countries are posited in the shape of a rectangular hyperbola, but given the high variations of these economies in terms of level of development, it will take a long time for actual convergence. But conventional wisdom in cross-country growth regression fails to incorporate the

Figure 2(a),(b). Income Inequality in Asia: 1971-2001

(a)

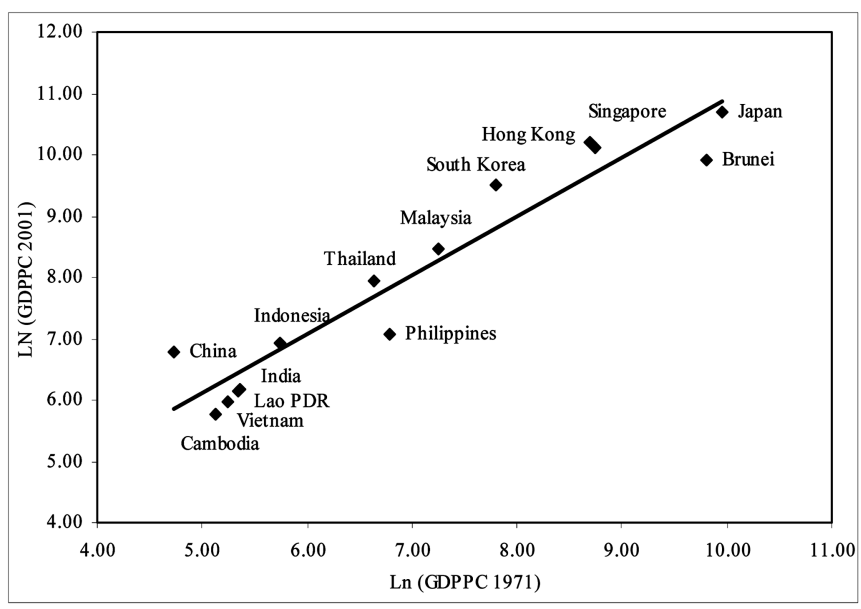

(b)

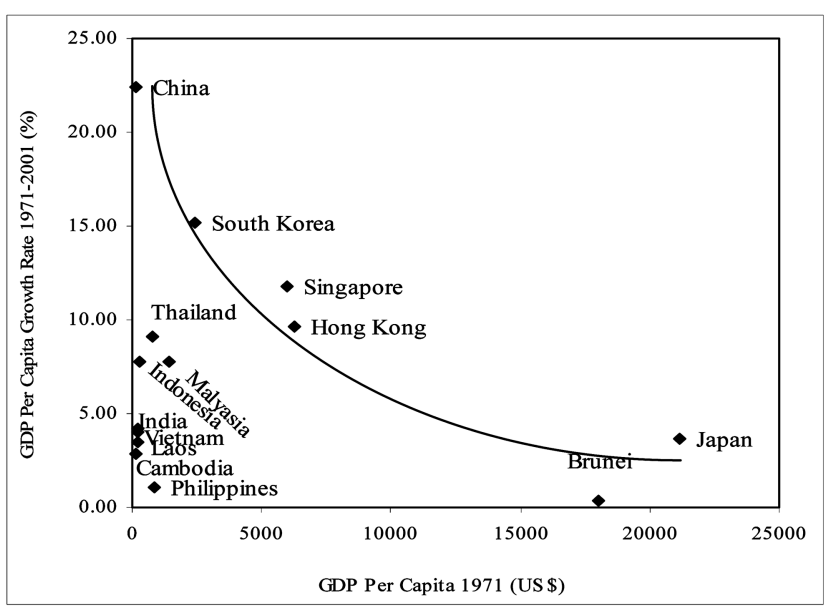


impact of either policy induced changes, or trading behavior or the role of strategic factors under globalization. Hence given the aforesaid tendency towards convergence, further income generating activities through trade among the partners would be beneficial to the countries under discussion.

\section{B. Inequality in Infrastructure}

Change in public capital structure is one of the important factors affecting the long-term economic development of any nation (Aschauer, 1989a). This is more so for the developing world. ${ }^{19}$ Beyond the neo-classical simplification of classifying different factors into only capital and labor, an economy's infrastructure network, broadly speaking, is the very socio-economic climate created by the institutions that serve as conduits of commerce. Some of these institutions are public, others private. In either case, their roles can be conversionary- helping to transform resources into outputs - or diversionary - transferring resources to non-producers. The dominant presence of the public sector in generating infrastructure services is guided by two fundamental motives of the welfare state: social equalizer and market failures. Infrastructure is a social concept of some especial categories of inputs external to the decision-making units (DMU) that contribute to economic development both by increasing productivity and by providing amenities to enhance the quality of life. Absence of such facilities in an economy or in a region may result in lower "productive efficiency" of the population. According to Hall and Jones (1996), these characteristics are substantial enough to explain most, if not all, of the differences in prosperity that separate nations today.

The linkage between infrastructure and economic growth is multiple and complex, because not only does it affect production and consumption directly, but it also creates many direct and indirect externalities, and involves large flows of expenditure thereby creating additional employment. Most of the studies on macroeconomic impact were generated after the 1980s. These studies suggest that infrastructure does contribute towards a hinterland's output, income and employment growth, and quality of life. ${ }^{20}$

In order to understand the impact of trading infrastructures on the trading behavior

\footnotetext{
${ }^{19}$ To be more specific, Aschauer (1989a, 1989b, 1989c) set off a long overdue dialogue between economists and politicians: decline in US productivity in 1980s was preceded by lower infrastructure investment. The works of Munnell (1990) confirmed these results.

${ }^{20}$ For a review of studies on impact of infrastructure on income, see, De and Ghosh (2005) and Ghosh and De (2004, 2005).
} 
of the major Asian nations we have segmented the infrastructure sector in four broad categories, namely, agriculture infrastructure (access to fertilizer consumption, irrigated land and agricultural machinery), economic infrastructure (access to electricity, telephones, personal computer, banking facility, and internet), social infrastructure (access to health facility, media, education, drinking water), and transport infrastructure (access to roadways, railways, airways and ports). We have normalized all infrastructure facilities across the countries in terms of either population or geographical area.

Instead of making a composite index of infrastructure services for the countries in Asia, following equation (5), we have tried to develop four indices for each of the category. These infrastructure development indices are given in Table 2. ${ }^{21} \mathrm{~A}$ look at this table helps us understand some interesting phenomena about the relative positions of the individual countries in infrastructure sector. A detailed scrutiny of the individual rankings bears a clear testimony to the prevalent consensus between popular belief and academic findings towards intense and rising

Table 2. Infrastructure in Asia in 2001

\begin{tabular}{lcccccccc}
\hline \multirow{2}{*}{ Countries } & \multicolumn{2}{c}{ AII $^{1}$} & \multicolumn{2}{c}{ EII $^{2}$} & \multicolumn{2}{c}{ SII $^{3}$} & \multicolumn{2}{c}{ TII $^{4}$} \\
\cline { 2 - 9 } Brunei & Score & Rank & Score & Rank & Score & Rank & Score & Rank \\
Cambodia & 1.59 & 9 & 6.09 & 5 & 13.43 & 3 & 2.09 & 7 \\
China & 0.38 & 15 & 0.17 & 15 & 8.02 & 15 & 0.24 & 13 \\
Hong Kong & 2.34 & 5 & 2.46 & 8 & 11.82 & 6 & 3.12 & 5 \\
India & 1.76 & 7 & 10.27 & 3 & 13.34 & 4 & 4.28 & 4 \\
Indonesia & 1.83 & 6 & 0.84 & 11 & 9.73 & 13 & 2.20 & 6 \\
Japan & 0.86 & 14 & 1.05 & 10 & 10.46 & 12 & 0.59 & 12 \\
Lao PDR & 6.33 & 1 & 12.37 & 1 & 15.82 & 2 & 8.08 & 1 \\
Malaysia & 0.97 & 11 & 0.27 & 14 & 8.05 & 14 & 0.23 & 14 \\
Myanmar & 0.95 & 12 & 5.60 & 6 & 10.67 & 10 & 1.40 & 10 \\
Philippines & 1.01 & 10 & 0.41 & 13 & 10.48 & 11 & 0.11 & 15 \\
Singapore & 0.91 & 13 & 1.44 & 9 & 11.51 & 8 & 0.67 & 11 \\
South Korea & 5.14 & 2 & 10.43 & 2 & 12.80 & 5 & 7.57 & 2 \\
Thailand & 4.17 & 3 & 9.27 & 4 & 16.12 & 1 & 5.95 & 3 \\
Vietnam & 1.63 & 8 & 2.53 & 7 & 11.70 & 7 & 2.06 & 8 \\
\hline Notes: & 2.55 & 4 & 0.74 & 12 & 10.93 & 9 & 1.42 & 9 \\
\hline
\end{tabular}

Notes: 1. Agriculture Infrastructure Index, 2. Economic Infrastructure Index, 3. Social Infrastructure Index, and 4. Transport Infrastructure Index.

\footnotetext{
${ }^{21}$ Due to limitation of space, we avoid placing the concerned weights, which were derived from PCA. Interested readers may contact author for further details.
} 
regional imbalance in basic infrastructures in Asia.

As expected, Japan, Singapore, Hong Kong and South Korea, have ranked higher positions in most of the infrastructure indices. On the other hand, LDCs in Asia have represented the lowest profile of infrastructure facilities. Thus, the overall picture of income growth is more or less maintained in infrastructure with some additional features. Here, Japan has consistently recorded the top most performance in all the four areas of infrastructures with South Korea, Singapore, and Hong Kong also achieving higher levels of infrastructure development.

For better understanding of the nature of the relationship between infrastructure facilities on one hand, and per capita income on the other, we have presented two scatter points in Figures 3(a,b). They suggest some preliminary configurations regarding the way each category of infrastructures is related to per capita income. Even in such a cross-country framework, infrastructure and income are clearly related in a polynomial way thereby making the role of infrastructure all the more important. It is evident from these scatter diagrams that developed countries are comparatively better endowed with infrastructure facilities. In both the figures, Japan, Singapore, Hong Kong and South Korea occupy the top right positions, and India, Cambodia, Laos, China, Vietnam and Philippines the bottom left. Indonesia, Thailand, and Malaysia reserve the middle positions. Another observation is that the scatter points are stretched from down left to top right direction thereby implying a clear positively sloped relationship.

Having seen the present income earning status and infrastructure profile of Asian countries, let us now turn to its trade profile and trade intensity.

\section{Intra-regional Trade and Trade Intensity}

It is interesting to note that most of the countries in Asia (except those in South Asia) have been export hawks. In terms of trade policies, most of the countries in Asia have been more liberal than South Asian countries though vast differences exist among countries within each region, especially Southeast and East Asia.

The degree of regional integration through trade has been rising fast over last few decades in Asia (Kawai, 2005). Table 3 reports changes in intra-regional trade for various economic groupings in the world over the period 1981 to 2004 . It shows that intra-regional trade in Asia has risen from 35.02 percent in 1981 to 58.76 percent in 2004 thereby indicates that almost 60 percent of Asia's trade is with itself. The recent share of intra-regional trade within Asia is still lower than that in the European Union (59.80 percent), but has exceeded that of the NAFTA 
Figure 3 (a), (b). Income-Economic Infrastructure Relationship in Asia in 2001

(a)

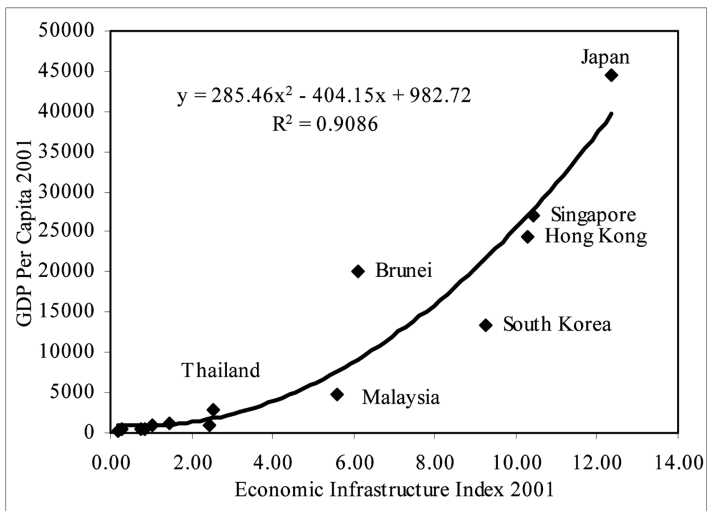

(b)

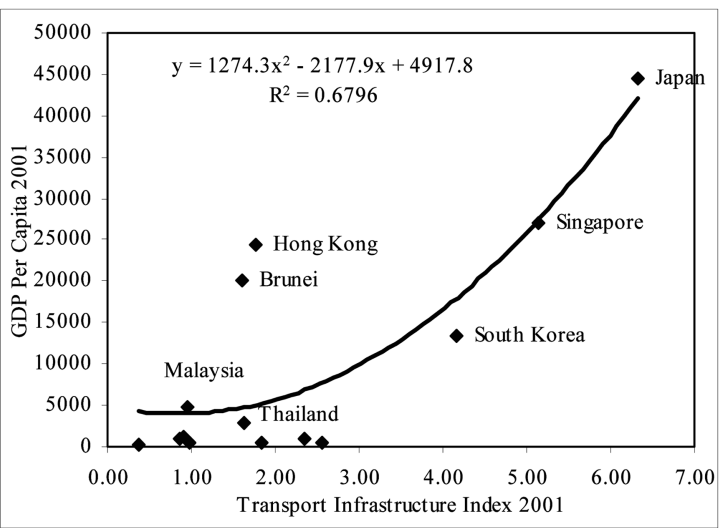

Table 3. Intra-Regional Trade in Asia

\begin{tabular}{lcccc}
\hline \multicolumn{1}{c}{ Region } & 1981 & 1991 & 2001 & 2004 \\
\hline Asia $^{1}$ & 35.02 & 45.98 & 57.44 & 58.76 \\
ASEAN $^{2}$ & 18.39 & 19.09 & 24.19 & 24.98 \\
NAFTA & 39.12 & 38.90 & 46.60 & 43.67 \\
EU $^{3}$ & 52.88 & 64.70 & 59.40 & 59.80 \\
\hline
\end{tabular}

Notes: 1. Asia includes ASEAN+4 countries, namely, Brunei, Cambodia, China, Hong Kong, India, Indonesia, Japan, Lao PDR, Malaysia, Myanmar, Philippines, Singapore, South Korea, Thailand, and Vietnam. 2. ASEAN 10 members. 3. EU 15 members.

Source: Calculated from Direction of Trade Statistics Year Book CD ROM 2006, IMF.

\section{(43.67 percent) in 2004.}

Within Asia, there are some interesting changes in intra-regional trade in recent period. Table 4 reports the country-wise intra-regional trade share in Asia. A close review of Table 4 points to the fact that all the countries in Asia except Vietnam 
have registered higher exports to each other in 2004, compared to 1991. However, there has been a deceleration in intra-regional exports in countries like Brunei, China, Lao PDR and Vietnam. Asia in 2004, compared to 2001. In regard to import, except China, Philippines and Singapore, rest 12 countries have imported more from Asia in 2004, compared to 1991. From the same table, a link between intra-regional trade growth and openness can be established for the countries lying on extremes. The highly open economies like Hong Kong and Singapore have grown consistently and engaged in more trading rapidly while the least open economy, like India (and partly Japan), has traded lower volumes. In the middle of these two extremes, we have countries such as South Korea, Malaysia, and Thailand, which have grown consistently rapidly and, at least in terms of trade-to-GDP ratio, appear to be highly open. These countries are not only open to countries in Asia but also to rest of the world.

Free trade area for a region can not be functionally operational until and unless there is a rise in intra-regional trade. Therefore, what follows is that Asian countries are now engaged in more intensified trading among each other due to which the

Table 4. Intra-Regional Trade Share in Asia

\begin{tabular}{|c|c|c|c|c|c|c|c|c|c|}
\hline \multirow[t]{3}{*}{ Countries } & \multicolumn{3}{|c|}{ Exports to Asia ${ }^{1}$} & \multicolumn{3}{|c|}{ Imports from $\mathrm{Asia}^{2}$} & \multicolumn{3}{|c|}{ Openness $^{3}$} \\
\hline & \multicolumn{9}{|c|}{$\%$} \\
\hline & 1991 & 2001 & 2004 & 1991 & 2001 & 2004 & 1991 & 2001 & 2004 \\
\hline Brunei & 67.20 & 81.04 & 73.95 & 57.34 & 74.94 & 76.73 & 101.50 & 79.20 & dna \\
\hline Cambodia & 7.88 & 8.82 & 12.56 & 56.45 & 64.04 & 83.84 & 28.04 & 91.72 & 140.52 \\
\hline China & 38.67 & 46.71 & 42.32 & 51.22 & 66.52 & 42.58 & 15.85 & 44.32 & 65.35 \\
\hline Hong Kong & 36.43 & 43.24 & 58.34 & 67.13 & 72.20 & 73.74 & 235.44 & 124.78 & 376.22 \\
\hline India & 18.71 & 22.43 & 23.89 & 14.07 & 27.33 & 22.25 & 14.31 & 19.53 & 41.64 \\
\hline Indonesia & 46.33 & 54.38 & 58.64 & 44.79 & 58.56 & 53.72 & 42.92 & 60.07 & 57.84 \\
\hline Japan & 29.39 & 33.39 & 40.60 & 26.78 & 38.10 & 41.34 & 15.84 & 18.17 & 22.07 \\
\hline Lao PDR & 31.15 & 47.87 & 36.57 & 83.77 & 91.20 & 85.87 & 25.99 & 50.38 & 70.81 \\
\hline Malaysia & 49.28 & 52.52 & 53.72 & 54.00 & 54.64 & 59.16 & 144.50 & 184.01 & 221.13 \\
\hline Myanmar & 39.66 & 54.35 & 69.37 & 78.46 & 86.14 & 90.52 & 4.43 & 1.01 & dna \\
\hline Philippines & 36.91 & 42.09 & 55.01 & 41.67 & 72.27 & 36.46 & 47.69 & 88.87 & 102.43 \\
\hline Singapore & 30.22 & 33.74 & 55.63 & 54.35 & 59.13 & 52.89 & 291.90 & 277.59 & dna \\
\hline South Korea & 39.84 & 41.35 & 46.32 & 39.24 & 41.36 & 45.99 & 51.96 & 69.06 & 83.83 \\
\hline Thailand & 40.90 & 41.52 & 50.82 & 53.67 & 50.86 & 55.15 & 67.18 & 110.89 & 136.38 \\
\hline Vietnam & 41.11 & 44.03 & 39.89 & 54.65 & 66.18 & 66.12 & 46.03 & 93.64 & 139.99 \\
\hline
\end{tabular}

Notes: 1. As percentage of total exports to Asian 15 economies listed in above table. 2. As percentage of total imports from Asian 15 economies listed in above table. 3. Trade as percentage of GDP at current price. 4.dna means data not available

Source: Calculated from Direction of Trade Statistics Year Book CD ROM 2006, IMF. 
region's intra-regional trade has grown up drastically in last few decades. Coefficients of trade intensity (alternatively, trade intensity indices) further strengthen the above findings. Table 5 shows that intra-regional trade intensity index for Asia was 2.96 in 2004, which was higher than those for NAFTA (2.48) or EU (1.84). This confirms that the degree of regional integration through trade in Asia is quite high and comparable to the levels seen in NAFTA or the EU. ${ }^{22}$

However, Asia's trade base will merit much discussion. The immediate concern for rising intra-regional trade is various trade barriers. There are ample evidences to show that an economic integration can only take place when intra-regional trade among the members is high (Ben-David, 1996). Question raised on the needs and availabilities of the required commodities from the respective members of Asia is not really a valid one. For, first of all, commodity production statistics among the members invalidate such logic. Secondly, it is the lack of strategic linkage or nonprice barriers which play the major role for lower traded volume over and above diplomatic intricacies. To attain higher intra-regional trade with a rapid pace, we need to encourage trade facilitation catalysts to function in the era of globalization. Even if a region witnesses rising intra-regional trade, benefits arising out of such rising trade will evaporate until and unless barriers to trade are minimized. Although Asian countries are opening up fast, barriers to trade still persist. A point can be made here with regard to import duties which often act as deterrent to trade. Let us turn to Figure 4, where scatters for the years 1991 and 2001 clearly show

Table 5. Intra-Regional Trade Intensity Index ${ }^{3}$

\begin{tabular}{ccccc}
\hline Region & 1981 & 1991 & 2001 & 2004 \\
\hline Asia $^{1}$ & 2.67 & 2.75 & 2.82 & 2.96 \\
ASEAN $^{2}$ & 4.82 & 4.43 & 4.15 & 4.23 \\
NAFTA $^{3}$ & 2.18 & 2.19 & 2.32 & 2.48 \\
EU $^{3}$ & 1.48 & 1.56 & 1.78 & 1.84 \\
\hline
\end{tabular}

Notes: 1. Asia includes ASEAN+4 countries, namely, Brunei, Cambodia, China, Hong Kong, India, Indonesia, Japan, Lao PDR, Malaysia, Myanmar, Philippines, Singapore, South Korea, Thailand, and Vietnam. 2. ASEAN 10 members. 3. EU 15 members. 4. Trade Intensity Index is calculated based on following formula:

$$
T_{i j}=\left(x_{i j} / X_{i t}\right) /\left(x_{w t} / X_{w t}\right)
$$

where $\mathrm{x}_{i j}$ and $\mathrm{x}_{w j}$ are the values of region $i$ 's exports and the world exports to region $j . \mathrm{X}_{j t}$ and $\mathrm{X}_{w t}$ are region $i$ 's total exports and total world exports.

Source: Calculated from Direction of Trade Statistics Year Book CD ROM 2006, IMF.

\footnotetext{
${ }^{22}$ In another study, findings of Kawai (2005) also confirmed the same.
} 
Figure 4. Barriers to Intra-Regional Trade in Asia during 1991 - 2001

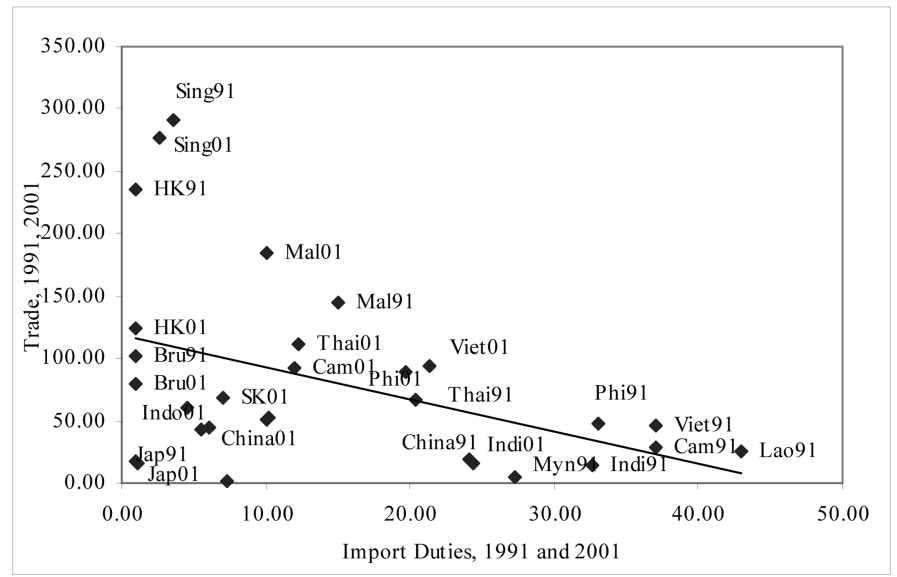

Notes: 1. Import duty calculated as percentage of total tax revenue collected by individual countries. 2 . Trade is considered as percentage of GDP Source: World Development Indicators 2006 CD ROM, Various issues.

Figure 5. Transport Infrastructure and Trade in Asia in 2001

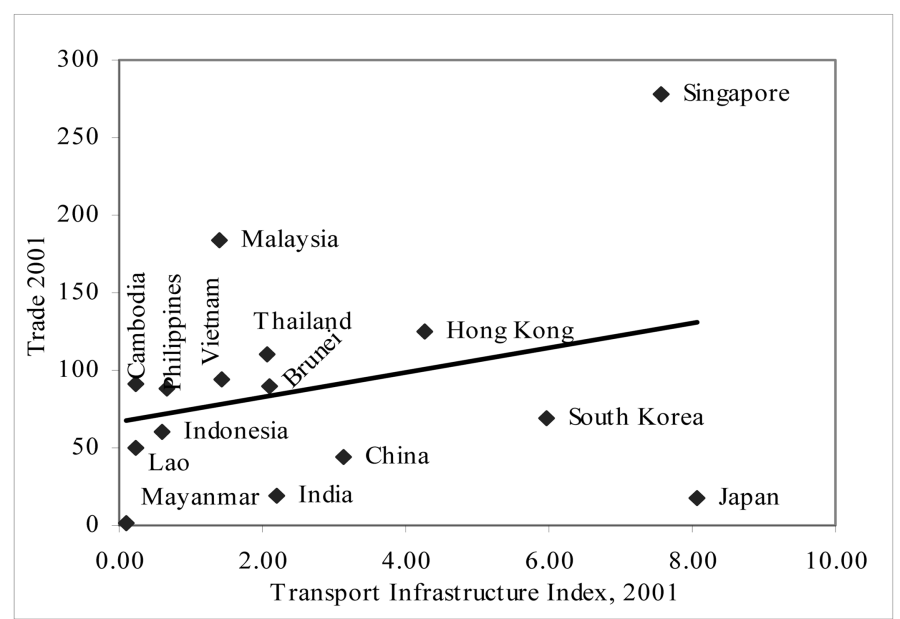

Notes: 1. Trade is taken as percentage of GDP. 2. Transport infrastructure index is taken from column 4 of Table 2 .

that barriers to trade (measured by import duties) have been working against total trade of the countries in Asia.

Again if we consider poor trading infrastructure facilities (poor quality of such facilities works against trade), we find that countries which are running fairly well 
developed transport infrastructure facilities have gone much ahead of others in reaping benefits from export market such as Singapore, Hong Kong, etc. Scatters plots reported in Figure 5 have captured this feature, where we found positive relationship between country's exports with its transport infrastructure facilities. Thus, strengthening trading infrastructure is equally important while mooting up plan to integrate Asia.

Finally, transaction costs have profound influence on trade. Higher the transaction costs, lower is the trade. Figure 6 captures a negative non-linear relationship between transaction costs and imports in context of 15 Asian economies for the year 2004. This relationship clearly points to the fact that transaction costs do influence trade. But does that relationship exogenously determined or can they be influenced by policy? This has been dealt in the next section in the framework of a partial equilibrium model.

\section{Impact of Infrastructure, Income and Transaction Costs on Trade}

Having discussed the interdependence of Asian countries in income, infrastructure and trade, let us turn to see the impact of trade barriers on bilateral trade with the help of the regression results. To assess such impact, as described in Section 2, we have used a modified Gravity model. The fixed effect least-square estimates are

Figure 6. Relative Importance of Transaction Costs in Asia

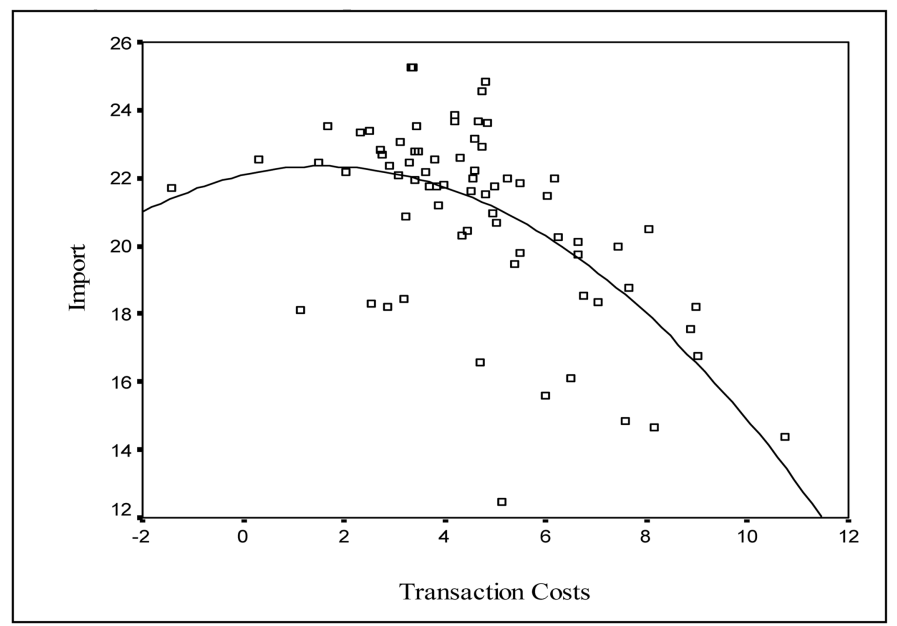

Note: Import and transaction costs are based on pooled bilateral trading pairs for 15 Asian economies (those listed in this paper) for the year 2004. 
provided in Table 6. Most of the variables do have expected signs as usual in the Gravity equations. As variables are used in natural logarithms except for dummies, estimated coefficients show elasticity. All the Models ( 1 to 3 ) explain about 60 percent of the variations in direction of trade flows. The most interesting result is the strong influence of transaction costs had on trade (at 1 percent level); the higher the transaction cost between each pair of partners, the less they trade. In other words, reduction in transactions costs between the trading partners will certainly

Table 6. Gravity Estimates: Fixed Effect Regression

\begin{tabular}{|c|c|c|c|c|c|c|}
\hline \multirow{2}{*}{ Variable } & \multicolumn{2}{|c|}{ Model 1} & \multicolumn{2}{|c|}{ Model 2} & \multicolumn{2}{|c|}{ Model 3} \\
\hline & coefficients & t-values & coefficients & t-values & coefficients & t-values \\
\hline Importing countries' GDP & 0.241 & 0.710 & 0.247 & 0.737 & & \\
\hline Exporting countries' GDP & $0.683 * * *$ & 2.349 & $0.716 * * *$ & 2.683 & & \\
\hline $\begin{array}{l}\text { Importing countries' per capita } \\
\text { GDP }\end{array}$ & 0.075 & 0.186 & & & 0.091 & 0.224 \\
\hline $\begin{array}{l}\text { Exporting countries' per capita } \\
\text { GDP }\end{array}$ & 0.093 & 0.306 & & & 0.361 & 1.276 \\
\hline $\begin{array}{l}\text { Importing countries' transport } \\
\text { infrastructure }\end{array}$ & 0.249 & 0.457 & 0.272 & 0.520 & 0.287 & 0.536 \\
\hline $\begin{array}{l}\text { Exporting countries' transport } \\
\text { infrastructure }\end{array}$ & 0.015 & 0.037 & 0.039 & 0.105 & 0.217 & 0.531 \\
\hline Importing countries' openness & 0.101 & 0.203 & 0.107 & 0.216 & 0.061 & 0.122 \\
\hline Exporting countries' openness & $0.919 * *$ & 3.224 & $0.912 * *$ & 3.226 & $0.721 * * *$ & 2.621 \\
\hline Transaction costs & $-0.729 *$ & -5.226 & $-0.736 *$ & -5.373 & $-0.837 *$ & -6.271 \\
\hline Importing countries' import duties & -0.024 & -0.038 & -0.056 & -0.093 & -0.041 & -0.064 \\
\hline Exporting countries' export duties & -0.137 & -0.692 & -0.144 & -0.739 & -0.142 & -0.709 \\
\hline $\begin{array}{l}\text { Importing countries' population } \\
\text { strength }\end{array}$ & 0.187 & 0.568 & 0.176 & 0.546 & 0.232 & 0.736 \\
\hline $\begin{array}{l}\text { Exporting countries' population } \\
\text { strength }\end{array}$ & 0.435 & 1.640 & 0.379 & 1.979 & $0.827 *$ & 4.043 \\
\hline $\begin{array}{l}\text { Importing countries' exchange rate } \\
\text { volatility }\end{array}$ & -0.011 & -0.031 & -0.009 & -0.027 & -0.018 & -0.053 \\
\hline $\begin{array}{l}\text { Exporting countries' exchange rate } \\
\text { volatility }\end{array}$ & 0.028 & 0.183 & 0.030 & 0.199 & 0.007 & 0.049 \\
\hline Distance & -0.530 & -0.919 & -0.517 & -0.903 & -0.416 & -0.715 \\
\hline Common border dummy & 1.054 & 1.304 & 1.031 & 1.286 & 0.933 & 1.143 \\
\hline Free trade dummy & 0.311 & 0.379 & 0.294 & 0.361 & 0.413 & 0.500 \\
\hline Sample size & 7140 & & 6720 & & 6720 & \\
\hline Adjusted $\mathrm{R}^{2}$ & 0.598 & & 0.602 & & 0.589 & \\
\hline DW & 2.084 & & 2.086 & & 2.117 & \\
\hline Serial Correlation & 0.059 & & 0.060 & & 0.077 & \\
\hline
\end{tabular}

Notes: The dependent variable is Ln(Import) *Denotes statistical significance at $1 \%$ level. **Denotes statistical significance at $5 \%$ level. $* *$ Denotes statistical significance at $10 \%$ level 
raise the trade by a very large proportion. As can be seen from the Table 6 , coefficients of transaction costs in all the three models are statistically most significant and always negative. For example, in the Model 3, the t-value is (-6.271) with an elasticity of 84 percent.

Some other important factors next to transaction costs are (i) GDP of exporting countries, (ii) openness of exporting countries, and (iii) population strength of exporting countries. But this is a rather common phenomenon as we are dealing with aggregate behaviors. As we have already seen that the rising openness is a necessary condition for speeding up the integration process, in our study openness of the exporting country has significant positive effect (at 1 percent level) on bilateral trade in all the models. Models 1 and 2 indicate that 1 percent increase in exporting country's openness will bring about 1 percent increase in trade.

Distance between any two partners of trade is certainly an important factor in determining the volume of trade for any bilateral transaction borne out to be negative but none is statistically significant. In all other cases, distance has not. In all other cases distance has not produced any significant impact on trade. Statistically speaking, this may be due to the fact that distance and transaction cost partly work in the same direction.

The importance of common land border in Asia is also shown in Table 6. Except Japan and Philippines, rest Asian countries do enjoy some natural geographical overland connectivity, very similar to that we see in case of EU and NAFTA. This is a great advantage for the Asian countries to facilitate higher intra-regional trade and mobility of skilled labor. Finally, total population (only exporting countries) has come out to exert a statistically significant positive impact on Asian trade through the chain of effective demand. Needless to mention that the rest of the variables have also produced the desired signs, but none of them has emerged as significant. On the whole therefore, the regression results are sufficiently robust for all the three alternative combinations of the Gravity model.

Model 4 (given in Table 7) shows that barriers to trade, represented by transaction costs and country's transport infrastructure (both exporting and importing), produce a significant positive effect on bilateral trade with the highest elasticity reaching at 1 percent level. Therefore, improved transport infrastructure facilities will help enhance intra-regional trade and speed up the economic integration process.

This study shows that besides distance and some other variables that are arbitrarily given, important determinants for rising intra-regional trade are transaction costs and transport infrastructure, which indicates that the lesser the barriers between the 
countries, the higher would be the expected trade. Hence, in order to enhance regional trade (and also regional integration) in Asia, the priority should be therefore to (a) control transaction costs, and (b) strengthen the chain of necessary trading infrastructure facilities, starting from the production point to the shipment point, and associated trade facilitation measures.

\section{Conclusions, Policy Relevance and Limitations of the Study}

A country or a region's trade volumes depend on many complex details of history, geography, income, infrastructure, administrative barriers, and the structure of demography. In this article we have found evidences towards explaining trade flows in terms of geography, trading costs, infrastructure, population and income of trading countries. Increasing integration of world goods and services are happening at rapid pace in an unprecedented way during last one decade than ever before. Countries which have successfully integrated themselves have gone far ahead in reducing costs of transportation in particular and other infrastructure services in general over time and space. EU is a clear example of such process. As liberalization continues to reduce artificial barriers, the effective rate of protection provided by costs of transportation and infrastructure services is now in many cases higher than the one provided by tariffs.

In order to attain any positive achievement towards this pan-Asian integration process, policy planning should emphasize on (i) strengthening infrastructural facilities, particularly transport infrastructure, and (ii) minimization of transaction costs. To do so, we have to intensify our intra-regional trade at much faster pace. We

Table 7. Gravity Model Estimates: Impact of Barriers to Trade

\begin{tabular}{lcc}
\hline \multirow{2}{*}{ Variables } & \multicolumn{2}{c}{ Model 4 } \\
\cline { 2 - 3 } & coefficients & t-values \\
\hline Transaction costs & $-0.197^{* * *}$ & -2.142 \\
Importing countries transport infrastructure & $-1.825^{*}$ & -10.401 \\
Exporting countries transport infrastructure & $-1.032^{* *}$ & -6.026 \\
Distance & $-0.993^{* * *}$ & -3.493 \\
Adjusted R & 0.741 & \\
DW & 1.526 & \\
Serial Correlation & 0.010 & \\
\hline
\end{tabular}

Notes: Gravity estimates are based on fixed effect OLS. The dependent variable is $\operatorname{Ln}(\operatorname{Import}) *$ Denotes statistical significance at $1 \%$ level. **Denotes statistical significance at $5 \%$ level. ***Denotes statistical significance at $10 \%$ level 
must make sure that removal of the barriers to trade and common border soould lead to raise income per capita of the smaller low-income countries. ${ }^{20}$

The analysis carried out in this paper place evidences to ascertain that the link between trade flows and trade costs has been based previously more on intuition than evidence, particularly in context of Asia. We found that variations in transaction costs along with trade mobility infrastructure facilities have significant influence on regional trade flows in Asia. When the tariffs have come down heavily, the economies of this region could potentially benefit substantially from higher trade subject to control of transaction costs. However, a number of obstacles block the realization of this potential. Among the most serious of these is rising transaction cost as an outcome of the visible and policy constraints on the regional trade and infrastructure system. Therefore, policy protection should tend to complement natural protection, lowering the variability of total trade costs.

This study is not beyond limitations. The possibility of endogeneity can not be excluded that greater bilateral trade will lead to higher values of trade mobility infrastructure facilities. The usage of trade mobility infrastructure facilities (port, aviation, telecommunication, rail, road, etc.) may improve with a country's import flows and lower trade costs, and if this endogeneity is present the estimated coefficients for the variable would be biased upward. So, to remove the endogeneity problem, we need to employ instrumental variables. As an extension of this study, perhaps, taking raw inputs of the trade mobility infrastructure index may be adopted to mitigate the endogeneity problem.

Here, we have been not able to indicate the country-specific direction of transaction costs and trade mobility from the estimated coefficients as the level of infrastructure endowment and preparedness for free trade differs across countries. The estimated elasticities may produce biased results in case of change of scale. From a policy perspective, the differences in trade flows with respect to the transaction costs and trade mobility suggest that different approaches towards reduction in trade costs (or to trade facilitation) will differentially affect imports of the region as a whole. Therefore, in order to better inform policy-making process, future research should be undertaken to complement the findings of this paper in following ways. First,

\footnotetext{
${ }^{23}$ See, for instance, Redding and Venables (2004) which shows that removing common borders between Germany and Czech, and also between the United States and Mexico have substantial effects on predicted income per capita in the smaller countries; income per capita of Czech and Mexico have gone up by 26 percent and 27 percent respectively presumably as a result of integration.
}

${ }^{24}$ Refer, Brooks et al (2005), Duval (2006), Chaturvedi (2006). 
the focus of this study is on the importance of transaction costs in context of Asia. Transaction costs and infrastructure measures are very much aggregative in nature. So, future study should attempt to decompose the two variables, and find the causal linkages of the variables with the trade flow separately. Second, the study has considered aggregate total trade and transaction costs in bilateral pairs. Future research should consider disaggregated trade and trade costs in a dynamic framework at least at the HS 4-digit level. Third, this paper has considered direct trade costs but omitted infrastructure costs. Variability in infrastructure endowments and costs thus need to be captured more accurately in the model provided the data is made available. Fourth, even though this paper considers relative trade barriers, one needs to ascertain theoretical foundations of the Gravity model by incorporating remoteness variable (trade weighted average distance from the rest of the world). ${ }^{25}$ Finally, in order to find out the relative robustness of the transaction costs, one may need to replace the transaction costs assessment methodology adopted here by other method(s).

In sum, the major concern towards rising intraregional trade in Asia is transaction costs. The challenge for Asian countries is to identify improvements in logistics services and related infrastructure that can be achieved in the short-to-medium term and that would have a significant impact on competitiveness of the Asian countries. Therefore, the need is to continuously upgrade trading infrastructure facilities and strengthen trade facilitation measures which will not only pave the way for sustained intraregional trade but also speed up the regional integration process towards establishing an FTA in near future.

\section{Acknowledgment}

An earlier version of the paper was presented at the Institute of Developing Economies (JETRO), Chiba, Japan on April 30, 2004, and at High Level Conference on Asia's Economic Cooperation and Integration, organized by the Asian Development Bank, held at Manila, Philippines on 1-2 July 2004. Author sincerely acknowledges the insightful comments provided by Dr. Buddhadeb Ghosh, Indian Statistical Institute, Calcutta. Usual disclaimer applies.

Received 24 December 2004, Accepted 20 July 2006

\footnotetext{
${ }^{25}$ For example, theoretically founded normal trade with resistances for both the pairs in the estimated Gravity equation may consider remoteness from rest of the world. Refer, Piermartini (2006)
} 


\section{References}

Anderson, J. E. (1979), A Theoretical Foundation for the Gravity Equation, American Economic Review 69, pp. 106-116.

Anderson, J. E., E. van Wincoop (2003), Gravity with Gravitas: A Solution to the Border Puzzle, American Economic Review 93, pp. 170-191.

Anderson, J. E., E. van Wincoop. (2004) Trade Costs, Journal of Economic Literature, Vol. XLII, No. 3, pp. 691 - 751.

Aschauer, D. A. (1989a), Is Public Expenditure Productive?, Journal of Monetary Economics 23.

Aschauer, D. A. (1989b), Public Investment and Productivity Growth in the Group of Seven, Economic Perspectives 13.

Aschauer, D. A. (1989c), Does Public Capital Crowd out Private Capital?, Journal of Monetary Economics 24.

Baier, S L, J. F. Bergstrand. (2001). The Growth of World Trade: Tariffs, Transport Costs, and Income Similarity, Journal of International Economics, Vol. 53, pp. 1-27

Balasaa, B. (1961). The Theory of Economic Integration, Homewood: Richard D. Irwin.

Barro, R. , X. Sala-i-Martin (1995), Economic Growth, McGraw Hill, New York.

Ben-David, Dan. (1996), Trade and Convergence among Countries, Journal of International Economics 40, pp. 297-298.

Bergstrand, J. H. (1985), The Gravity Equation in International Trade: Some Microeconomic Foundations and Empirical Evidence, Review of Economics and Statistics 67, pp. 474-81

Bergstrand, J. H. (1989), The Generalized Gravity Equation, Monopolistic Competition, and the Factor-Proportions Theory in International Trade, Review of Economics and Statistics 71, pp. 143-53.

Bougheas, S. et. al. (1999) Infrastructure, Transport Costs, and Trade, Journal of International Economics 47, pp. 169-89.

Brakman, S., H. Garretsen, and C. V. Marrewijk. (2001). An Introduction to Geographical Economics, Cambridge University Press, Cambridge.

Brooks, D. H., Roland-Host, D. and Zhai, F. (2005). Asia's Long-term Growth and Integration: Reaching beyond Trade Policy Barriers. ERD Policy Brief No. 38, Asian Development Bank, Manila

Chaturvedi, S. (2006). An Evaluation of the Need and Cost of Selected Trade Facilitation Measures in India: Implications for the WTO Negotiation, ARTNeT Working Paper No. 4, UNESCAP, Bangkok

Clark, X., D. Dollar, and A. Micco (2004). Port Efficiency, Maritime Transport Costs and Bilateral Trade, Working Paper 10353, NBER, Cambridge.

David, D. (1998). The Home Market Effect, Trade and Industrial Structure, American Economic Review, Vol. 88, No. 5, pp. 1264-1276

De, P. (2004). Transaction Costs as Barriers to Economic Integration in Asia: An Empirical 
Exploration, RIS Discussion Paper No. 77, Research and Information System for Developing Countries, New Delhi

De, P. (2005). Affect of Transaction Costs on International Integration in the Asian Economic Community, in Asian Economic Cooperation and Integration: Progress, Prospects, Challenges. Asian Development Bank (ed.), Manila.

De, P. (2006). Regional Trade in Northeast Asia: Why Do Trade Costs Matter?, CNAEC Research Series 06-02, Korea Institute for International Economic Policy (KIEP), Seoul.

De, P., B. Ghosh. (2005). Effects of Infrastructure on Regional Income in the Era of Globalisation: New Evidence from South Asia, Asia Pacific Development Journal, Vol. 12, No.1, pp. 81-107

Deardorff, A. (1998). Determinants of Bilateral Trade: Does Gravity Work in a Neo-Classical World?. In: J. Frankel (ed.), Regionalization of the World Economy, University of Chicago Press, Chicago.

Duval, Yann. (2006). Cost and Benefits of Implementing Trade Facilitation Measures under Negotiations at the WTO: An Exploratory Survey, ARTNeT Working Paper No. 3, UNESCAP, Bangkok

Eichengreen, B., D. A. Irwin (1998). The Role of History in Bilateral Trade Flows. In: J. Frankel (ed.), Regionalization of the World Economy, University of Chicago Press, Chicago.

Fink, C., A. Mattoo, and I. C. Neagu (2002). Trade in International Maritime Services: How Much Does Policy Matter? The World Bank Economic Review 16, pp. 451-79.

Fink, C., A. Mattoo, and I. C. Neagu, (2005). Assessing the Impact of Communication Costs on International Trade?, Journal of International Economics, Vol. 67, pp. 428 $-445$

Francois, J., M. Manchin. (2006). Institutional Quality, Infrastructure, and the Propensity to Export, CEPR, London

Fruchter, B. (1967), Introduction to Factor Analysis, Affiliated East West Press, New Delhi.

Georgakopoulos, T., C. C. Paraskevopoulos, and J. Smithin (1994). Economic Integration between Unequal Partners, Edward Elgar, Aldershort.

Ghosh, B., P. De. (2004). How Do Different Categories of Infrastructure Affect Development: Evidence from Indian States, Economic and Political Weekly, Vol. 38.

Ghosh, B., P. De. (2005). Investigating the linkage between Infrastructure and Regional Development: Era of Planning to Globalisation, Journal of Asian Economics, Vol. 15, No. 1. pp. 1-28

Glock, R. and A. K. Rose (2002), Does a Currency Union Affect Trade? The Time-Series Evidence, European Economic Review 46.

Hall, R.E. and C. I. Jones (1996), The Productivity of Nations, Working Paper No. 5812, NBER, Cambridge.

Harrigan, J. (1993). OECD Imports and Trade Barriers in 1983, Journal of International Economics, Vol. 34, pp. 91-111 
Hummels, D. (1999), Have International Trade Costs Declined?, Working Paper, University of Chicago Business School, Chicago.

Hummels, D. (2001a). Towards a Geography of Trade Costs, Working Paper, Purdue University, West Lafayette

Hummels, D. (2001b). Time as Trade Barrier, Working Paper, Purdue University, West Lafayette

Kawai, M. (2005). Trade and Investment Integration and Cooperation in East Asia: Empirical Evidence and Issues, in Asian Economic Cooperation and Integration: Progress, Prospects, Challenges. Asian Development Bank (ed.), Manila.

Limao, N., A. J. Venables (2001). Infrastructure, Geographical Disadvantage, Transport Costs, and Trade, The World Bank Economic Review 15, pp. 451-479.

Linneman, H. (1966), An Econometric Study of International Trade Flows, North-Holland, Amsterdam.

Munnell, A. H. (1990). How Does Public Infrastructure Affect Regional Economic Performance, Conference Proceedings, Conference Series No. 34, Federal Reserve Bank of Boston, Held at Harwich Port, Massachusetts, June, 1990.

Nordås, H.K, R. Piermartini (2004). Infrastructure and Trade, Staff Working Paper ERSD-2004-04, Economic Research and Statistics Division, World Trade Organization, Geneva.

Obstfeld, M, K. Rogoff, (2000). The Six Major Puzzles in International Macroeconomics: Is There a Common Cause?, in NBER Macroeconomics Annual 2000. B. S. Bernanke and K. Rogoff (eds.), MIT Press, Cambridge, pp. 339-390

Piermartini R. (2006). Modeling Methods for Trade Policy II: Gravity Models, Handout of WTO/ESCAP Second ARTNeT Capacity Building Workshop on Trade Research, UNESCAP, Bangkok, 17-21 April.

Redding, S. and A. J. Venables (2004). Economic Geography and International Inequality, Journal of International Economics 62, 53-82.

Stewart, J. Q. (1947). Suggested Principles of Social Physics, Science 106, 179-180.

Stewart, J. Q. (1948). Demographic Gravitation: Evidence and Applications, Sociometry 11, 31-58.

Tinbergen, J. (1962). Shaping the World Economy, The Twentieth Century Fund, New York.

Wilson, J. S., C. L Mann, and, T. Otsuki. (2003). Trade Facilitation and Economic Development: A New Approach to Quantifying the Impact, The World Bank Economic Review, Vol. 17, No. 3, pp. 367-389

World Trade Organization (WTO). (2004). Doha Development Agenda and Trade Facilitation Issues, Brussels. 